\title{
Estimation of soil reinforcement by the roots of four post- dam prevailing grass species in the riparian zone of Three Gorges Reservoir, China
}

\author{
ZHONG Rong-hua',2 (iD http://orcid.org/oooo-0002-0570-2998; e-mail: zhrhua1987@163.com \\ HE Xiu-bin' ${ }^{\text {ID }}$ http://orcid.org/oooo-ooo1-6786-1284; e-mail: Xiubinh@imde.ac.cn

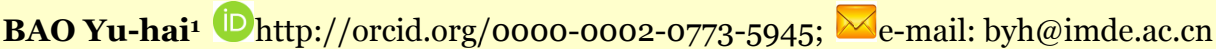 \\ TANG Qiang3 iDhttp://orcid.org/oooo-0oo3-0861-9943; e-mail: qiangtang@imde.ac.cn \\ GAO Jin-zhang1,2 Dhttp://orcid.org/oooo-0oo3-1776-1490; e-mail: jzhgao@imde.ac.cn
}

YAN Dan-dan1,2 (D http://orcid.org/oooo-ooo2-3242-8357; e-mail: 1012040365@qq.com

WANG Ming-feng1,2 iD http://orcid.org/oooo-0oo3-2181-0304; e-mail: w1129338066@163.com

LI Yü,2 Dhttp://orcid.org/oooo-0oo1-7004-439X; e-mail: liyu100oooo@163.com
1 Key Laboratory of Mountain Surface Processes and Ecological Regulation, Institute of Mountain Hazards and Environment, Chinese Academy of Sciences, Chengdu 610041, China
2 University of Chinese Academy of Sciences, Beijing 10oo49, China
3 State Key Laboratory of Urban and Regional Ecology, Research Center for Eco-environmental Sciences, Chinese Academy of Sciences, Beijing 100085, China

\begin{abstract}
Citation: Zhong RH, He XB, Bao YH, et al. (2016) Estimation of soil reinforcement by the roots of four post-dam prevailing grass species in the riparian zone of Three Gorges Reservoir, China. Journal of Mountain Science 13(3). DOI: $10.1007 / \mathrm{s} 11629-014-3397-2$
\end{abstract}

(C) Science Press and Institute of Mountain Hazards and Environment, CAS and Springer-Verlag Berlin Heidelberg 2016

\begin{abstract}
Soil erosion and bank degradation is a major post-dam concern regarding the riparian zone of the Three Gorges Reservoir. The development and succession of vegetation is a main countermeasure, especially to enhance bank stability and mitigate soil erosion by the root system. In this study, the roots of four prevailing grass species, namely, Cynodon dactylon, Hemarthria altissima, Hemarthria compressa, and Paspalum paspaloides, in the riparian zone were investigated in relation to additional soil cohesion. Roots were sampled using a single root auger. Root length density (RLD) and root area ratio (RAR) were measured by using the WinRHIZO image analysis system. Root tensile strength $\left(\mathrm{T}_{\mathrm{R}}\right)$ was performed using a manual
\end{abstract}

Received: 27 November 2014

Accepted: 4 February 2015 dynamometer, and the soil reinforcement caused by the roots was estimated using the simple Wu's perpendicular model. Results showed that RLD values of the studied species ranged from $0.24 \mathrm{~cm} / \mathrm{cm}^{3}$ to $20.89 \mathrm{~cm} / \mathrm{cm}^{3}$ at different soil layers, and RLD were significantly greater at $\mathbf{0}-10 \mathrm{~cm}$ depth in comparison to the deeper soil layers $(>10 \mathrm{~cm})$. RAR measurements revealed that on average $0.21 \%$ of the reference soil area was occupied by grass roots for all the investigated species. The measured root tensile strength was the highest for $P$. paspaloides (62.26 $\mathrm{MPa})$ followed by $C$. dactylon (51.49 $\mathrm{MPa}), H$. compressa $(50.66 \mathrm{MPa})$, and $H$. altissima (48.81 MPa). Nevertheless, the estimated maximum root reinforcement in this investigation was $22.5 \mathrm{kPa}$ for $H$. altissima followed by $H$. compressa $(21.1 \mathrm{kPa}), P$. paspaloides $(19.5 \mathrm{kPa})$, and $C$. dactylon $(15.4 \mathrm{kPa})$ at 
o-5 $\mathrm{cm}$ depth soil layer. The root cohesion values estimated for all species were generally distributed at the $0-10 \mathrm{~cm}$ depth and decreased with the increment of soil depth. The higher root cohesion associated with $H$. altissima and $H$. compressa implies their suitability for revegetation purposes to strengthen the shallow soil in the riparian zone of the Three Gorges Reservoir. Although the soil reinforcement induced by roots is only assessed from indirect indicators, the present results still useful for species selection in the framework of implementing and future vegetation recovery actions in the riparian zone of the Three Gorges Reservoir and similar areas in the Yangtze River Basin.

Keywords: Bank stabilization; Root area ratio; Root tensile strength; Soil reinforcement; Riparian zone; Three Gorges Reservoir

\section{Introduction}

The role of plant roots in preventing bank and slope from erosion has been widely acknowledged (e.g., Gray and Sotir 1996; Nilaweera and Nutalaya 1999; Simon and Collison 2002; Gyssels and Poesen 2003; De Baets et al. 2008). Welldeveloped plant root systems may function in improving soil aggregate stability (Li et al. 1990), infiltration rate (Glinski and Lipiec 1990; Li et al. 1991), bulk density (Glinski and Lipiec 1990; Li et al. 1991, 1993), moisture content (Gyssels et al. 2005), shear strength (Gray and Leiser 1982; Simon and Collison 2002), grain size, organic matter content and chemical composition (Sarkar et al. 1979; Glinski and Lipiec 1990; Amezketa 1999). In general, combined with the mechanical reinforcing and hydrological effects (e.g., water transpiration, infiltration), roots can substantially enhance soil strength (De Baets et al. 2008; PollenBankhead and Simon 2010). However, the magnitude of hydrological effects on bank stabilization may be smaller than the ones of mechanical reinforcing (Simon et al. 2002, 2006). Roots are characterized by strong tensile strength, whereas soils, in contrast, are characterized by weak in tensile force and high in compression (Gyssels et al. 2005). Thus, soil reinforcement is the integrated effect of soil and roots (De Baets et al. 2008). Roots mobilize their tensile strength as the soil sheared so as to transfer shear stresses that developed in the soil block to the root fibers by way of the tensile resistance of the roots (Ennos 1990) or by way of the interface friction between the soil and roots (Gray and Barker 2004).

Root reinforcement (or called root cohesion) depends on several essential variables, including root distribution patterns in terms of rooting depth, root number, root diameter, root length density, and root mass density (Wu et al. 1979); root morphological structure, such as tap-like roots and fibrous-like roots (Reubens et al. 2007; Burylo et al. 2011; Adhikari et al. 2013); and biomechanics characteristics of roots, such as root tensile strength (Gray and Barker 2004; Mattia et al. 2005) and pull-out strength (Stokes et al. 1996; Dupuy et al. 2005; Norris 2005; Giadrossich et al 2013). Previous studies have revealed the root tensile strength and root diameters following a power relation (Bischetti et al. 2005; Tosi 2007; De Baets et al. 2008; Burylo et al. 2011; Adhikari et al. 2013). This well-known relationship reveals that the developed robust fine roots would contribute more to soil strengthening compare with coarse roots per unit root area roots (De Baets et al. 2008; Adhikari et al. 2013).

To understand the soil reinforcement due to the addition of roots, many researches have been conducted in the past three decades. Many methods, including lab analysis, field investigation and modeling calculation of soil-root interactions (De Bates et al. 2008; Wu 2013), were developed to assess the enhancement of soil strength. The most popular method is the simple perpendicular root model (also called Wu's model), which was developed by Wu et al. (1979) and Waldron and Dakessian (1981). In this model, the increase in soil shear strength is estimated using the information of root distribution and root tensile strength. One crucial assumption of the Wu's model is roots are totally activated as the soil sheared and achieve maximum tensile strength so that all roots rupture simultaneously (De Baets et al. 2008). In reality, roots with different tensile strength would rupture progressively accompanying the redistribution of shear stress (Pollen and Simon 2005). Consequently, this model calculates the peak values of root cohesion and hence overestimates the root reinforcement provides for soil (Mickovski et al. 2009). However, the overestimation is assumed almost the same for all species which means that their relative efficiency is well predicted 
via the Wu et al model (De Baets et al. 2008). For a better estimate of root reinforcement, more complex methods relied on roots distortional features during soil shearing have been established. Pollen and Simon (2005) proposed a dynamic fiber bundle model (i.e., the RipRoot model), which considered the progressive process of root breaking and the redistributed manner of shear stress during soil shearing. Mickovski et al. (2009) proved that the fiber bundle method providing more accurate root cohesion assessments than the Wu's model. Greenwood (2007) developed a straightforward computer program, i.e., SLIP4EX, which is the combined hydrological effect and mechanical reinforcement of plant roots on slope stability. In addition, some literature has suggested solving the root cohesion overestimation problem use empirically determined correction factors (e.g., Fan and Su 2008; Hubble et al. 2010). Recently, Mao et al. (2014) used two numerical modeling approaches, namely, discrete element method (DEM) and standard implicit finite element method (FEM), to evaluate root reinforcement. However, although it is not the most accurate or realistic one, the Wu's model continues to be one of the most widely applied methods for initial root cohesion estimation due to a simplified process and fewer input variables is required compared with others models (Burylo et al. 2011). Therefore, the Wu's model was applied in this study to arrange several grasses in relation to their potential for soil strengthening and to compare their availability for soil conservation withstand bank erosion in the riparian zone of Three Gorges Reservoir (TGR).

The Three Gorges Dam, regarded as one of the world's largest hydropower projects, intercepts the main channel of the Yangtze River at the outlet of the upper subbasin and controls a drainage area of nearly $1.0 \times 10^{6} \mathrm{~km}^{2}$ (Tang et al. 2014). The Three Gorges Reservoir (TGR), which has a storage capacity of 39.3 billion $\mathrm{m}^{3}$, was fully implemented in 2008. Since then, the reservoir has experienced water level fluctuations, from $145 \mathrm{~m}$ a.s.l. in the summer (Between May and September) to $175 \mathrm{~m}$ in the winter (Between October and April). Thus, an artificial riparian zone with a vertical height of 30 $\mathrm{m}$ and a total area of $349 \mathrm{~km}^{2}$ was created (Fu et al. 2010; Ye et al. 2011; Tang et al. 2014). The riparian zone of the TGR has undergone substantial degradation since its initial impoundment in 2003 (Xu et al. 2013). The flow regulation and altered hydrology regime, coupled with extreme storm events and wave actions, have resulted in bank retreat, disappearance of native plants, intensive soil erosion, and sediment deposition in the water level fluctuating zone of TGR (Bao et al. 2013; Tang et al. 2014).

The reversal of hydrological regime (submergence in winter and exposure in summer) and prolonged inundation duration result in the loss of pre-dam terrestrial vegetation. Annual plants, such as Bidens tripartita and Echinochloa crusgalli, and perennials, such as Cynodon dactylon, are currently dominant species in the natural recovery areas (Ye et al. 2013). To restore the riparian ecosystem and to control bank erosion, a number of species (i.e., C. dactylon, Hemarthria altissima, Hibiscus syriacus, Morus alba, Salix variegate, Salix chaenomeloides, and Taxodium distichum) which are highly resistant to long-term flooding have been planted in the riparian zone, and many vegetation recovery areas have been selected along Zhong, Wanzhou, and Zigui counties in recent years (Ye et al. 2012, 2014). Among the above mentioned riparian species, $C$. dactylon and $H$. altissima have been reported for their role in reducing erosion during concentrated flow (Tenten et al. 2010). Nevertheless, knowledge related to the mechanical functions of these species in the riparian zone of TGR is lacking.

This study attempts to evaluate the root reinforcement of one native grass species, $C$. dactylon, and three plantation species, $H$. altissima, Hemarthria compressa, and Paspalum paspaloides at their mature period, developing in the riparian zone of TGR, applying the model developed by Wu et al (1979) to compare species' potential in erosion control and bank stability. Thus, roots of all species were collected in the laboratory, and the information of root distribution and root tensile strength with soil depth were measured.

\section{Materials and Methods}

\subsection{Study area}

Plant root samples were collected in the 
riparian zone along the mainstream of the Yangtze River near Shibao town, Zhong County of Chongqing Municipality in the middle section of the TGR $\left(30^{\circ} 24^{\prime} 53^{\prime \prime N}, 108^{\circ} 10^{\prime} 25^{\prime \prime} \mathrm{E}\right.$; Figure 1$)$. The regional climate is dominated by humid subtropical monsoons. The mean annual temperature was $18.2^{\circ} \mathrm{C}$ and the mean annual precipitation was $1150 \mathrm{~mm}$, and rainfall mainly occurs in the rainy season from May to September (Shi et al. 2011). The soils of the riparian zone are dominated by purple soil, which is an early weathering product of the Jurassic rocks and is susceptible to detachment erosion (He 2003). Purple soil is classified as an orthic entisol in the Chinese Soil Taxonomic System, a regosol in the FAO Taxonomy, and an entisol in the USDA Taxonomy (Zhao et al. 2007; He et al. 2009). The dominated silt soil texture is found in the sampling sites (Tang et al. 2014), and the cohesion of nonrooted soil ranges from $19.9 \mathrm{kPa}$ to $30.9 \mathrm{kPa}$ and the corresponding friction angle ranges from $15.1^{\circ}$ to $27 \cdot 1^{\circ}$ under natural moisture content (Liu 2010). According to $\mathrm{Lu}$ et al. (2010), pre-dam vegetation was dominated by annual plants, including Digitaria ciliaris, Leptochloa chinensis, and Setaria viridis; perennials, including $C$. dactylon, Capillipedium assimile and $H$. altissima; and ligneous plants, including Ficus tikoua, Pterocarya stenoptera, and Vitex negundo. However, biodiversity was dramatically reduced because of anti-season flooding, and annual plants (e.g., $E$. crusgalli and $B$. tripartita) and perennials $(C$. dactylon) became prevalent species (New and Xie 2008; Ye et al. 2013; Zhang et al. 2013).

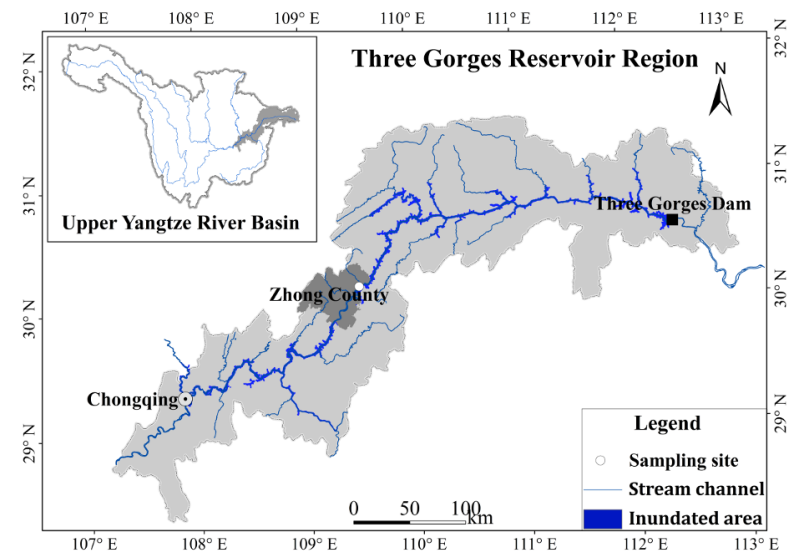

Figure 1 Map of the Three Gorges Reservoir Region and location of the field sampling site.

\subsection{Field sampling}

In the present investigation, one native grass which is a post-dam prevalent species, i.e., $C$. dactylon, and three plantation species which are now developed well in the riparian zone of TGR, i.e., $H$. altissima, $H$. compressa, and $P$. paspaloides were selected from the study area. C. dactylon, which is widely distributed in the riparian zone of pools, lakes, and rivers, also in abandoned field and hillside, is a perennial Poaceae plant, creeping by means of stolons and rhizomes, 10 to 30 high culms (Sun and Sylvia 2006). C. dactylon has wide adaptability to flooding and drying environment, and has strong ability to stabilize soil against erosion (FAO 2014). $H$. altissima and $H$. compressa are perennial gramineous erect grasses normally floating at the edges of pools, lakes, and rivers, also in damp places, ditches, banks and abandoned paddy fields (Sun and Sylvia 2006). $P$. paspaloides is also a perennial gramineous grass, which is creeping by means of horizontal stolons and often growing in moist environment (Chen and Sylvia 2006).

Field sampling was conducted in May 2014 when the water level was low and the riparian zone was mostly exposed. Sampling was carried out on flat terraces. Root-soil matrix samples were collected from four adjacent areas: one natural growth area and three plantation areas based on the topography in the riparian zone. The selected plantation herbs were $H$. altissima, $H$. compressa, and $P$. paspaloides from plantation areas; and $C$. dactylon from the natural recovery area. The altitude distribution for each species was different, yet all species were found in $173 \mathrm{~m}$ elevation. Thus, in each area, five sampling plots $(1 \mathrm{~m} \times 1 \mathrm{~m})$ were randomly selected along the $173 \mathrm{~m}$ elevation. At each sampling plot, the roots of $\mathrm{o}-30 \mathrm{~cm}$ soil depth was sampled using a single root auger (Eijkelkamp Agrisearch Equipment Model 05.01) with $8 \mathrm{~cm}$ in diameter and $15 \mathrm{~cm}$ in length. The root auger was drilled into the soil until $30 \mathrm{~cm}$ of sampling depth was reached. At first a $15 \mathrm{~cm}$ cylindrical sample was drilled, and then a second drilling was performed down to $30 \mathrm{~cm}$. Subsequently, $0-5,5-10,10-15$, 15-20, 20-25, and 25-30 cm soil cylinders were cut. Samples were placed in plastic bags and taken back to the laboratory. Root samples were washed out of the soil as gently as possible through a 0.5 
$\mathrm{mm}$ sieve and then dead roots were removed according to the method provided by Hefting et al. (2005). Before measurements, all live roots were sealed in self-styled bags and placed in a cold chamber at $5^{\circ} \mathrm{C}$ (Burylo et al. 2011).

\subsection{Laboratory measurement}

The roots in the bags were spread out on a $20 \times 15 \mathrm{~cm}$ glass tray filled with $2-3 \mathrm{~mm}$ of deep distilled water and scanned using a flatbed scanner with a transparency unit adapter (Epson Photo 1600, Seiko Epson Corporation). Scanning was performed at 400 dpi resolution in positive mode and 8-bit greyscale. All image enhancements were turned off. All images were taken using the same settings as that of the scanning system. The larger root samples, which did not fit in the tray, were separated to avoid overlapping during scanning. The scanned images were analyzed for root diameter and total root length in each layer distribution using WinRHIZO (Version Pro 2009c, Canada). The RLD ( $\left.\mathrm{cm} / \mathrm{cm}^{3}\right)$ was defined as the ratio of the root length to soil volume excavated and was calculated using the total root length divide by the volume of the soil cylinder is filled with roots for each species and different depth (Smit et al. 2000). The computation was given as Formula (1).

The RAR distribution information with soil depth is required for estimating the contribution of roots to soil shear strength. RAR was defined as the proportion of the roots per unit area to the crosssectional area of soil cylinder (Waldron and Dakessian 1981). However, in the present experiment, RAR values for each species at different depths were calculated via the RLD and root diameter information of all the studied species from each soil depth based on the assumption that all roots were vertical growth (De Baets et al. 2008). The soil column length (0.05 $\mathrm{m}$ in this study) is divided by total root length per soil depth to obtain the amount of root segments at each soil depth $(0.05 \mathrm{~m})$ for all species. The reference area of soil and the mean cross-sectional area of roots were measured as presented by De Baets et al (2008). In this case, RAR at different soil depth classes (0.05 $\mathrm{m})$ was calculated using the following equation (Formula 2). Although the total number of roots was overestimated using Formula 2, their mean cross-sectional area at a certain depth was underestimated because of the fact that roots cross under a certain angle and their cross-sectional area would be larger (Adhikari et al. 2013). Therefore, the overestimation of total number of roots will be somewhat compensated by the underestimation of root cross-sectional areas (De Baets et al. 2008). All roots were conserved in a $15 \%$ alcoholic solution after the RLD and RAR were measured (Bischetti et al. 2005).

In order to estimate root reinforcement, the root tensile properties were also required. The root tensile strength $\left(\mathrm{T}_{\mathrm{R}}\right)$ was measured using a manual dynamometer (F. S. $=50 \mathrm{~N}$, accuracy $=0.1 \%$ F. S.) and two clamping jaws which employed in a similar investigation (Adhikari et al. 2013). One clamping jaw was attached to the end of the dynamometer and the other one was fastened to the pedestal. The peak of root break was recorded by the test device. The dynamometer was calibrated and verified in the laboratory before root testing. The root samples were checked before testing and only the undamaged roots were selected for the testing. The roots of $50 \mathrm{~mm}$ were selected for testing. In addition, before testing, the representative diameter value of testing roots was determined using a digital Vernier caliper at three different positions along the root length. The two ends of root were fixed to the clamps of the device, subsequently moved at a $10 \mathrm{~mm} / \mathrm{min}$ constant speed to apply a tensile force to the root. Rubber strips were attached to the clamps so as to increase the friction between the clamp and the root and to avoid damaging the root (De Baets et al. 2008). Root break near the ends may be caused by root mechanical damage rather than tensile force, hence only specimens which break near the middle position was selected (Bischetti et al. 2005). The dynamometer automatic logged the tensile force imposed on the root, and $\mathrm{T}_{\mathrm{R}}(\mathrm{MPa})$ was calculated by means of Formula (3). Roots tensile tests were finished within one week after the root distribution measured.

In this present experiment, the Wu's model was utilized to evaluate the soil reinforcement by the roots. The model was based on the assumption that roots were vertical growth so that the tensile force was transported to the roots during soil shearing. This useful assumption evaluates the root reinforcement on an average for all possible root 
orientations (De Baets et al. 2008). As the soil sheared, an observably additional cohesion was provided by plant roots to increase soil shear strength (Waldron and Dakessian 1981). Thus, the increased soil shear strength caused by roots is treated as an additional cohesion $\left(\mathrm{C}_{\mathrm{r}}\right)$ (Adhikari et al. 2013). The calculation is presented as follows (Formula 4).

According to $\mathrm{Wu}$ et al. (1979), root deformation and stretch contribute to afford enough interface friction, confining stress and anchorage force to bind the roots within soil and to withstand slip or pullout. A tangential component resisting shear and a normal component increasing the confining pressure on the shear plane are used to calculate the tensile force mobilized in roots during soil shearing (Wu et al. 1979). The principle of the Wu's model is that all roots simultaneously achieve the maximum tensile strength and break at the same time as the soil sheared (Simon et al. 2006). On the basis of the assumption, the estimated soil cohesion caused by the full mobilization roots at a certain depth is given by Formula (5).

The sensitivity analyses by Wu et al. (1979) revealed that the value of the bracketed term in Formula (5) was ranging from 1.0 to 1.3 corresponding to the variations in $\theta\left(40^{\circ}-90^{\circ}\right)$ and $\varnothing\left(25^{\circ}-40^{\circ}\right)$ and the average value of 1.2 was selected to simplify the Formula 5 . According to the analyses of Thomas and Pollen-Bankhead (2010), a $25^{\circ}$ friction angle was selected considering the silt texture of the sampling sites, and a $45^{\circ}$ shear distortion angle was assumed. Consequently, the bracketed term in Formula (5) was equal to 1.04, and the expression applied in the present study to

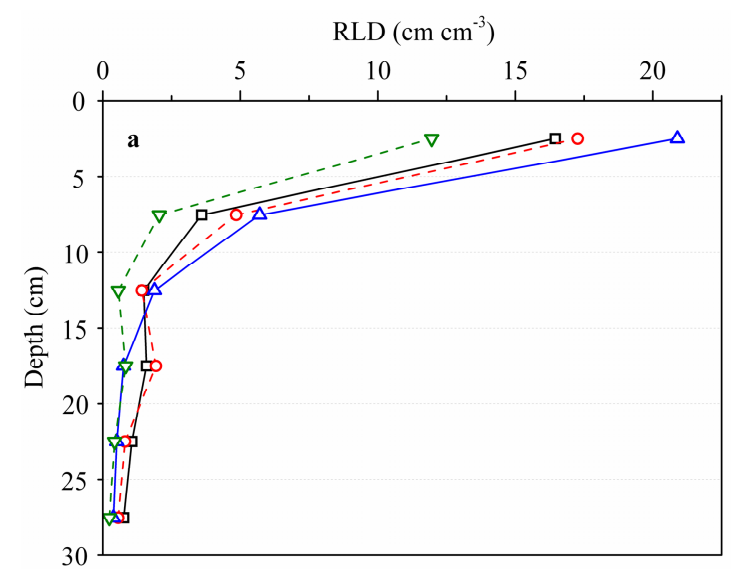

estimate the additional cohesion in silt soils is Formula (6).

\subsection{Statistics and analysis}

Previous investigations have reported that the $\mathrm{T}_{\mathrm{R}}$ increased with decreasing root diameter $(\mathrm{D}, \mathrm{mm})$ presenting a non-linear and inverse relationship as Formula (7) (De Baets et al. 2008; Burylo et al. 2011; Adhikari et al. 2013). Thus, power law equations between $\mathrm{D}$ and $\mathrm{T}_{\mathrm{R}}$ were fitted and plotted. Furthermore, because the $\mathrm{D}$ varied in this investigates, covariance analysis (ANCOVA) was applied to test the difference in $T_{R}$ between species and between recovery types. The original $T_{R}$ values were logarithmically transformed before ANCOVA so as to confirm the normal distribution hypothesis. In addition, Kruskal-Wallis nonparametric test was performed to investigate if the RAR and $\mathrm{C}_{\mathrm{r}}$ differ significantly according to species and soil depths, as the sample numbers was small and the data was non-normal distributed. All procedures were performed using SPSS software (IBM SPSS Statistics 20.0) and plotted using OriginPro software (Version 8.6).

\section{Results}

\subsection{Root distribution with depth}

The average RLD of the four species studied were measured at a soil depth of $0-30 \mathrm{~cm}$. Roots were mainly distributed at the $0-10 \mathrm{~cm}$ soil layer, and the RLD showed a general decreasing tendency with the increment of soil depth (Figure 2a). The

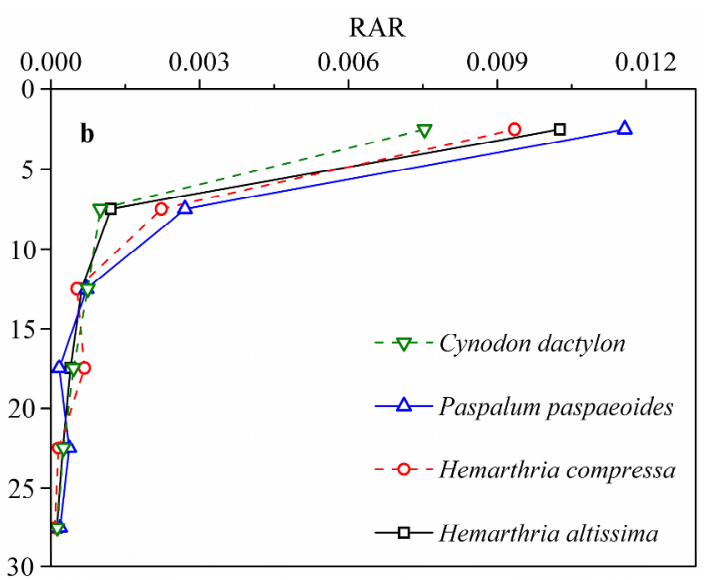

Figure 2 Distribution of (a) Root length density and (b) Root area ratio at different soil depth for the species studied. 
maximum RLD estimated in the surface soil layer $(0-5 \mathrm{~cm})$ were $20.89 \mathrm{~cm} / \mathrm{cm}^{3}$ for $P$. paspaloides, $17.27 \mathrm{~cm} / \mathrm{cm}^{3}$ for $H$. compressa, $16.45 \mathrm{~cm} / \mathrm{cm}^{3}$ for $H$. altissima, and $11.96 \mathrm{~cm} / \mathrm{cm}^{3}$ for $C$. dactylon. The RLD in the topsoil $(0-10 \mathrm{~cm})$ was observed to be notably greater $(p<0.001)$ compared with the subsoil $(10-30 \mathrm{~cm})$.

The resulting values of RAR distribution for different species showed a significant decrease with soil depth (Table 1). However, the distribution of RAR showed no differences between species concerning the entire sampling depth (Figure 2b). The maximum RAR estimated in the surface soil layer $(0-5 \mathrm{~cm})$ for $P$. paspaloides, $H$. altissima, $H$. compressa, and $C$. dactylon were $1.16 \%, 1.03 \%$, $0.93 \%$, and $0.75 \%$, respectively. The RAR for all studied species were close to $O$ at the soil layer of approximately $30 \mathrm{~cm}$. The average value of RAR was $0.21 \%$ for all studied species. Significant differences for the RAR between species in different soil layers were detected (Table 2).

\subsection{Root tensile strength changes with root diameter}

Figure 3 shows the results of root tension tests. A non-linear relationship between $T_{R}$ and root diameter was observed in all the species studied, and the $\mathrm{T}_{\mathrm{R}}$ decreased significantly with increasing root diameter. The statistical significance and values of $\alpha$ and $\beta$ of the equations are given in Table 3 . The adjusted $R^{2}$ values of the fitted power curves for all species studied were higher than 0.95 (Table 3 ). $\mathrm{T}_{\mathrm{R}}$ was also calculated for different root diameter classes and at every $5 \mathrm{~cm}$ soil depth. The mean $\mathrm{T}_{\mathrm{R}}$ value studied species.
Table 1 Differences of root area ratio (RAR) with soil depth within each species revealed by the Kruskal-Wallis test (test statistic $\mathrm{H}$ and probability value p). With increasing soil depth, the RAR decreased dramatically for all

\begin{tabular}{|c|c|c|c|c|}
\hline & H. altissima & H. compressa & P.paspaeoides & C. dactylon \\
\hline $\mathrm{H}$ & 56.715 & 53.771 & 55.416 & 55.854 \\
\hline$p$ & $<0.001$ & $<0.001$ & $<0.001$ & $<0.001$ \\
\hline
\end{tabular}

Table 2 Differences of root area ratio (RAR) and root reinforcement $\left(\mathrm{C}_{\mathrm{r}}\right)$ with species at different soil depth revealed by the Kruskal-Wallis test (test statistic $\mathrm{H}$ and probability value $p$ ).

\begin{tabular}{|c|c|c|c|c|c|c|c|}
\hline \multicolumn{2}{|c|}{ Depth(cm) } & $0-5$ & $5^{-10}$ & $10-15$ & $15-20$ & $20-25$ & $25-30$ \\
\hline \multirow{2}{*}{ RAR } & $\mathrm{H}$ & 30.675 & 33.841 & 20.911 & 32.611 & 20.223 & 31.715 \\
\hline & $p$ & $* * *$ & $* * *$ & $* * *$ & $* * *$ & $* * *$ & $* * *$ \\
\hline \multirow{2}{*}{$\mathrm{C}_{\mathrm{r}}$} & $\mathrm{H}$ & 14.874 & 16.897 & 13.263 & 16.074 & 7.829 & 6.680 \\
\hline & $p$ & 0.002 & 0.001 & 0.004 & 0.001 & 0.052 & 0.083 \\
\hline
\end{tabular}

Note: Significance levels: ${ }^{* * *} p<0.001$.

Table 3 Parameter values of the power law equations between root diameters and root tensile strength for different species

\begin{tabular}{|l|c|c|c|c|c|c|}
\hline Species & Mean $\mathrm{T}_{\mathrm{R}}(\mathrm{MPa})$ & $\mathrm{N}$ & $a$ & $\beta$ & $\mathrm{R}^{2}$ & $p$ \\
\hline H. altissima & $48.81 \pm 2.60$ & 102 & 8.75 & 1.47 & 0.97 & $* * *$ \\
\hline H. compressa & $50.66 \pm 2.37$ & 128 & 13.83 & 1.24 & 0.97 & $* * *$ \\
\hline P. paspaeoides & $62.26 \pm 3.42$ & 118 & 25.36 & 0.77 & 0.95 & $* * *$ \\
\hline C. dactylon & $51.49 \pm 2.23$ & 141 & 23.44 & 0.71 & 0.98 & $* * *$ \\
\hline
\end{tabular}

Notes: Mean \pm standard error, $\mathrm{N}$ is the number of roots valid tested per species. Significance levels: ${ }^{* *} p<0.001$.

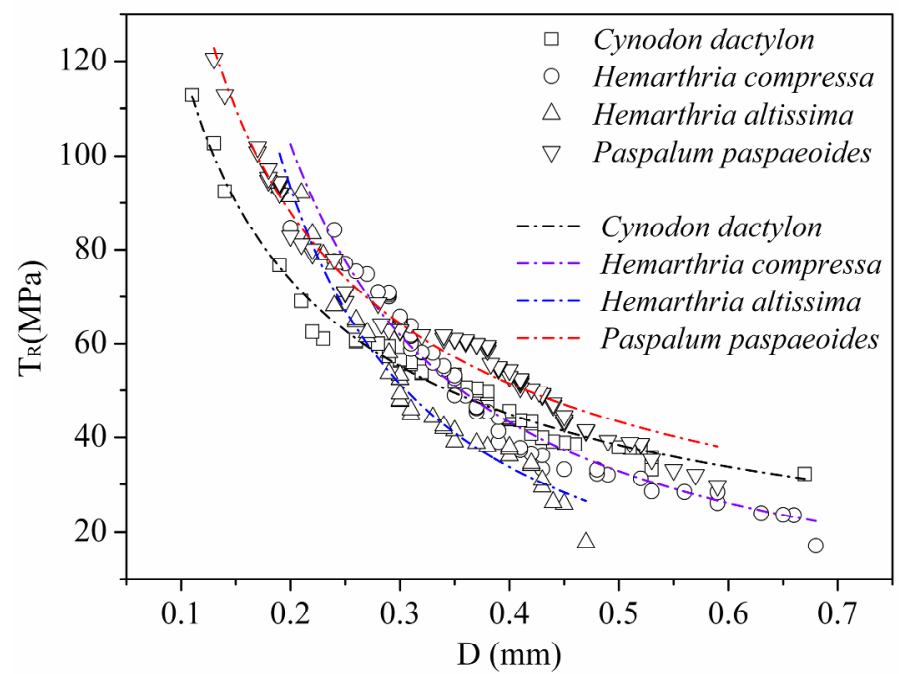

Figure 3 Root tensile strength ( $\left.\mathrm{T}_{\mathrm{R}}, \mathrm{MPa}\right)$ plotted against root diameter (D, $\mathrm{mm}$ ) for the species investigated. Points and curves represent the observed values and the predicted values, respectively.

(average values at total soil profile layer) of each grass was estimated. Results showed that the mean $\mathrm{T}_{\mathrm{R}}$ varied among four species, $P$. paspaloides (62.26 MPa) indicated the highest mean $\mathrm{T}_{\mathrm{R}}$ value followed by $C$. dactylon (51.49 MPa), H. compressa 
(50.66 MPa), and $H$. altissima (48.81 MPa). The comparison of $\mathrm{T}_{\mathrm{R}}$ and root diameter classes revealed a power relationship which similar to those found in many related investigations (Greenway et al. 1984; Simon and Collison 2002; Bischetti et al. 2007; De Baets et al. 2008; Comino et al. 2010; Adhikari et al. 2013).

ANCOVA results showed that $T_{R}$ differed significantly between species, but not significantly among revegetation types (Table 4). The roots of $C$. dactylon were less resistant to tension compared with other species for diameters less than $0.25 \mathrm{~mm}$, whereas $H$. compressa had the strongest roots. However, when the root diameters were larger than $0.3 \mathrm{~mm}, H$. altissima had the weakest roots and $P$. paspaloides had the strongest roots. Note that $T_{R}$ values of the $H$. altissima and $H$. compressa decreased more dramatically along with the root diameter increment (with larger $\beta$ values) and tended to fall slowly and be consistent with two other grasses when the root diameter was above $0.5 \mathrm{~mm}$.

\subsection{Root reinforcement}

In order to estimate the root reinforcement, $T_{R}$ values per root diameter class ( $0.1 \mathrm{~mm}$ steps) were recalculated following the parameters of the power equations showed in Table 3. Following the Wu's model, the $\mathrm{C}_{\mathrm{r}}$ value, which was the root reinforcement provided to soil, was given by Formula (6). The results showed that the average $\mathrm{C}_{\mathrm{r}}$ values for an entire soil profile were 4.90, 4.69, 4.42 , and $3.16 \mathrm{kPa}$ for $H$. compressa, $H$. altissima, $P$. paspaloides, and $C$. dactylon, respectively. According to the RAR and $\mathrm{T}_{\mathrm{R}}$ distribution, the increase of soil shear strength per soil depth attributes to the presence of roots for all species was also evaluated (Figure 4). The results indicated that the $\mathrm{C}_{\mathrm{r}}$ values decreased dramatically with increasing soil depth for all species and were significantly different between species within 0-20 cm depth (Table 2). Nevertheless, no significant difference was observed for $\mathrm{C}_{\mathrm{r}}$ values between species at the soil depth below $20 \mathrm{~cm}$. The maximum additional soil cohesion was found in the surface soil layer $(\mathrm{O}-5 \mathrm{~cm})$ for all grass species. The largest reinforcement effect was provided by $H$. altissima, which showed an increase of $22.47 \mathrm{kPa}$ of soil cohesion at $0-5 \mathrm{~cm}$ depth where was
Table 4 Significant differences (Sig. Diff.) of root tensile strength $\left(T_{R}\right)$ for different species and revegetation types (ANCOVA, Tukey HSD test, $\alpha=$ 0.05)

\begin{tabular}{|c|c|c|c|c|}
\hline Species & Sig. & iff. & Reveg. types & Sig. Diff. \\
\hline H. altissima & $\mathrm{A}$ & & \multirow{3}{*}{ Plantation } & \multirow{3}{*}{ A } \\
\hline H. compressa & A & & & \\
\hline P. paspaloides & A & B & & \\
\hline C. dactylon & & B & Natural & A \\
\hline
\end{tabular}

Note: Different letters indicate significant differences.

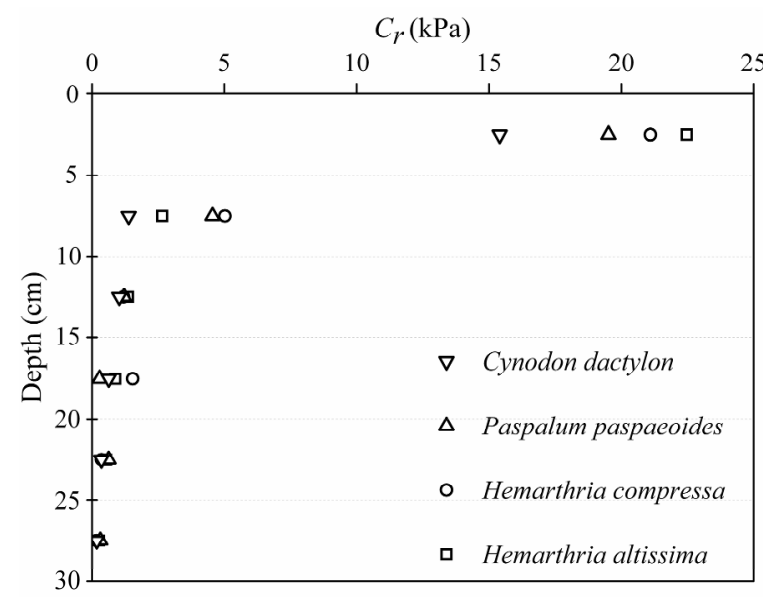

Figure 4 The mean root cohesion $\left(C_{r}, \mathrm{kPa}\right)$ for the grasses studied at each soil depth.

occupied by many roots and $0.27 \mathrm{kPa}$ at $25-30 \mathrm{~cm}$ depth where only a few roots are developed. In contrast, $C$. dactylon presented the least efficiency for the shallow bank erosion control with the values of $C_{\mathrm{r}}$ varying from $0.18 \mathrm{kPa}$ at $0-5 \mathrm{~cm}$ depth to $15.40 \mathrm{kPa}$ at $25-30 \mathrm{~cm}$ depth. H. compressa and $P$. paspaloides showed an intermediate potential with values ranging from 0.25 to approximately 20 $\mathrm{kPa}$ in different soil layers.

\section{Discussion}

\subsection{RLD and RAR distribution with depth}

The RLD measured in this experiment generally distributed in the topsoil $(0-10 \mathrm{~cm})$. De Baets et al. (2007) attributed this result to the more efficiently of soil moisture uptake in the upper layer compare with the deeper depth. In addition, high RLD in the topsoil is a natural phenomenon that has been proven by many previous studies (Pollen and Simon 2005; De Baets et al. 2008; Mickovski et al. 2009; Burylo et al. 2011; Adhikari et al. 2013; Polvi et al. 2014). According to the root 
distribution information, $P$. paspaloides could provide the maximum potential to reduce concentrated flow erosion, because most of its roots were concentrated in the topsoil $(\mathrm{o}-10 \mathrm{~cm})$ in comparison to the other three investigated grass species (De Baets et al. 2007).

The Kruskal-Wallis test revealed the significantly different RAR between species at varying soil depths (Table 2). Environmental heterogeneity and genetic diversity can explain this variability. As stated by Coutts et al. (1999) and Genet et al. (2005), many environmental factors (e.g., climate, seasons, and altitude) have important influence on root morphology and distribution. Furthermore, soil characteristics, such as soil structure and texture (Quine et al. 1991), soil bulk density (Gyssels et al. 2005), soil water and soil nutrients (Hodge 2004), could intensely affect root system development. However, in the present study, individuals of all species were collected on the adjacent sites, at a distance of a few meters from each other. Thus, environment heterogeneity and the differences of soil properties might not be the key reason responding for the RAR variability. The differences of RAR could be explained by plant-plant interactions, especially interspecific and intraspecific competition (Craine 2006), and the genetic variability of the species (Burylo et al. 2011). In addition, variability in RAR may be caused by errors in sampling and measurements in the laboratory.

\subsection{Root tensile strength-diameter relationships}

Tension tests revealed that with an increasing root diameter, $T_{R}$ decreased following a power law. As mentioned by many authors, this relationship indicates that thick roots are weak to withstand tension compared with thin roots (Mattia et al. 2005; De Baets et al. 2008; Burylo et al. 2011; Adhikari et al. 2013; Polvi et al. 2014). The $T_{R}$ values herein for similar root diameters are mostly lower than the ones of several grass species from the Mediterranean environment in the Southeast Spain (De Baets et al. 2008) and the Italian Alpine environment (Comino et al. 2010), but higher than the ones of Vetiveria zizanioides in semi-arid climate (Mickovski and Beek 2009) and Lotus corniculatus and Trifolium pretense from the Italian Alpine environment (Comino et al. 2010).
Furthermore, the $T_{R}$ values of the small roots (o$0.5 \mathrm{~mm}$ ) herein were higher than the ones measured at the same diameter classes for shrubs and trees from the riparian zone of the Upper Truckee River and Canyon de Chelly National Monument in the United States (Simon et al. 2006; Pollen-Bankhead et al. 2009) and lower than desert shrub species in the riparian zone of the Lower Colorado River (Adhikari et al. 2013). These observations may be caused by the different root composition of varying plants. Genet et al. (2005) and Zhang et al. (2014) revealed that the strength properties of roots were intensely determined by cellulose content and higher content of cellulose and lignin generated more robust roots. In contrast, the higher lignin/cellulose ratio will decrease the Young's modulus (Hathaway and Penny 1975). Consequently, fibrous roots (e.g., grass and herbs) with higher lignin content are stronger in tensile strength than tap-like roots of (e.g., trees and shrubs) with low lignin content (Burylo et al. 2011). In this case, the grasses studied with fibrous root system in the present investigation would have high lignin content and thus strong root tensile strength. In addition, the result of the different methods applied might be result in this difference. Potential errors may be observed in the data readings because a manual dynamometer was used in this study to test the root tensile force.

In general, the values of $\alpha$ and $\beta$ observed in this experiment were in the same magnitude of values as reported in many similar investigations. Mattia et al. (2005) and De Baets et al. (2008) described that several grass species were characterized by low $\alpha$ value and high $\beta$ value (more than 1). For shrubby species, several investigations have reported the values of $\alpha$ and $\beta$ varying from 4.4 to 91.2 and from 0.45 to 1.75 , respectively (Mattia et al. 2005; De Baets et al. 2008; Burylo et al. 2011). For trees, several literature (Bischetti et al. 2005; Genet et al. 2005) have revealed that the values of $\alpha$ varied from 0.11 to 0.52 , but $\beta$ ranged from 18.4 to 60.15 at a high level compared with the present investigation (0.71 and 1.47). In general, species with high values of $\alpha$ and low values of $\beta$ provide the most robust roots (Burylo et al. 2011). For this reason, roots of $P$. paspaloides and $C$. dactylon could be afforded the strongest tensile stresses. These results are confirmed by the consequence of the root tensile 
strength measured (Figure 2). Recently, several studies questioned the role of fine roots $(0-2.0 \mathrm{~mm})$ for reinforcing soil because of their short length and their rapid turnover could be insufficient to prevent slippage during the soil shearing (Stokes et al. 2009; Day et al. 2010; Schwarz et al. 2010). Nevertheless, in the present study, fine roots still have a large tensile strength and most of roots ranged from $0.1 \mathrm{~mm}$ to $1 \mathrm{~mm}$ in diameter, which implies that these grasses have a strong capacity for reinforcing soil. In other words, if the fine roots are suppressed, soil shear strength would decrease. Similar conclusions were also reached by other investigations (e.g., Mattia et al. 2005; De Baets et al. 2008; Comino et al. 2010; Burylo et al. 2011; Adhikari et al. 2013). Thus, the role of - fine roots in soil reinforcement cannot be neglected.

\subsection{Comparison of grasses for soil reinforcement}

The values of root cohesion $\left(\mathrm{C}_{\mathrm{r}}\right)$ were evaluated using the model developed by $\mathrm{Wu}$ et al. (1979) mostly varied from $1 \mathrm{kPa}$ to $23 \mathrm{kPa}$ at the o$20 \mathrm{~cm}$ soil layers and decreased to less than $1.0 \mathrm{kPa}$ at the soil depth of $20-30 \mathrm{~cm}$. The values of $\mathrm{C}_{\mathrm{r}}$ calculated using the Wu's model in Comino et al. (2010) were similar to the values estimated in this study. However, the $\mathrm{C}_{\mathrm{r}}$ values in the present are higher than the cohesion values of grass roots published in Burylo et al. (2011). These values were lower than most of the values reported by Mattia et al. (2005) and De Baets et al. (2008) for the Mediterranean environment. The varying $\mathrm{C}_{\mathrm{r}}$ values for different species could be explained by many factors, such as the diverse plant size, devices to measure root tensile strength, and environmental heterogeneity (De Bates et al. 2008). However, the most important factor could be the architectural characteristics of the roots, such as the spatial distribution of RAR, the branching pattern, RD or RLD, the angle of root growing, and root fractal features (Reubens et al. 2007). In the present study, all the species investigated were featured by fibrous roots architecture, whereas the information on angle of roots developing and root fractal characteristic are lacking. Hence, more experiments are needed to understand the architectural characteristics of the roots and their influence on soil cohesion.
The $\mathrm{C}_{\mathrm{r}}$ analysis showed that $H$. compressa and $H$. altissima provide more soil reinforcement compared with other species with regard to the total soil profile. Nevertheless, the root reinforcement of the two species is not significantly different compared with $P$. paspaloides. By contrast, a significant difference exists between $C$. dactylon and other studied species. $C$. dactylon presents the least efficiency for soil reinforcement in Figure 4, which is opposite to the results of root tensile strength (Figure 3). These inconsistent results can be explained by the different RAR values revealed in Figure $2 b$. Additionally, these results confirmed the opinion that the differed $T_{R}$ in interspecies maybe contribute less to erosion control and bank stabilization compared with differences in root distribution of interspecies, which were highlighted by Abernethy and Rutherford (2001) and De Baets et al. (2008).

However, the results of the present investigation should be applied with caution. As mentioned before, the $\mathrm{C}_{\mathrm{r}}$ values estimated using the model by Wu et al. (1979) were the peak values, hence, this model overstate the root reinforcement offered to the soil. Thus, the $\mathrm{C}_{\mathrm{r}}$ values calculated by Wu's method should be only applied for ranking species regarding their potential in bank stabilization and can not be seen as the actual values (Mattia et al. 2005; De Baets et al. 2008; Brylo et al. 2011). In addition, the values of root cohesion are only assessed from indirect indicators (i.e., RAR, root tensile strength). Therefore, in situ tests need to be performed or more perfect models need to be used (e.g., RipRoot, FEM, and DEM) for further reasonable estimations. However, the results showed in the present investigation could be beneficial to species selection for erosion control purposes.

Specific to the riparian zone, Abernethy and Rutherfurd (2001) and Docker and Hubble (2008) have reported the $\mathrm{C}_{\mathrm{r}}$ values observed in Australian riparian species were falling in the similar range of the ones estimated in the present study. However, the $\mathrm{C}_{\mathrm{r}}$ values reported for riparian trees by Pollen and Simon (2005) and Pollen-Bankhead and Simon (2010) were lower, whereas the values for riparian shrubs measured by Adhikari et al. (2013) were higher than the values obtained from the current study. Note that in the present study, trees and shrubs species were not investigated. 
Therefore, the order of root cohesion within different root systems (e.g., trees, shrubs, and herbs) cannot be decided in the riparian zone of TGR. Moreover, the seasonal submerging could have critical effect on plants in both aboveground growth and root development. Nevertheless, the root samples were excavated only at the $173 \mathrm{~m}$ a.s.l of the riparian zone. Thus, more investigations need to be performed to understand the effect of inundation on roots.

\subsection{Implications for revegetation in the riparian zone of TGR}

The vegetation in riparian zone is critical to control soil erosion and to improve bank stabilization (Adhikari et al. 2013), and to intercept pollutants (Ye et al. 2014). Numerous roots in the upper soil were observed in the present investigation for all species, which contribute to erosion reduction during concentrated flow (De Baets et al. 2007). In addition, roots within soil also reduce the bank face angle in some degree. Simon et al. (2006) reported that the bank with an increase of $5.5 \mathrm{kPa}$ root cohesion would reduce the bank angle by $10^{\circ}-15^{\circ}$. The estimated values of root cohesion in the present study are lower than $5.5 \mathrm{kPa}$ at an average, thus, a smaller bank face reduction could be inferred. It is noted that the grass species from this experiment are expected to play a role only in shallow bank stabilization because roots only distributed at a soil depth of o$0.3 \mathrm{~m}$. A related suggestion was given by Adhikari et al (2013), who reported that shrub species in the riparian zone of the lower Colorado River might only be effective in stabilizing the topsoil at a depth of $0.3 \mathrm{~m}$. De Baets et al (2008) also proposed that shrub and grass species from the Mediterranean environment on hill slope or terrace walls might only be active in stabilizing the top $0.5 \mathrm{~m}$.

The root distribution and root cohesion values of these plantation species are higher than the values of $C$. dactylon from the natural recovery area (Figures 2 and 4). This result implies that the planted species investigated in the present study are highly adaptive to the reversal of flooding time in the riparian zone of TGR. Furthermore, this result demonstrates that planted species may provide preferable soil reinforcement compared with natural species in the study area. Ye et al (2014) documented that the recovery approach in the riparian zone of TGR affects soil quality. The changed soil would affect the plants growth and root development. However, more investigations should be performed to verify these conclusions.

In a related study in the TGR region, Arundinella anomala, $H$. compressa, and $C$. dactylon were reported for their significant potential for reducing soil erosion combined with their roots and leaves during concentrated runoff (Tenten et al. 2010). This literature further confirmed the potential of grass roots from the riparian zone of TGR on soil reinforcement. However, the exact implication of revegetation using the above grasses will still need more experiments to investigate the definite soil strengthening from several specific sites where bank stabilization is desired. Nonetheless, combined with a marked adaptability to flooding and high-efficiency resistance to erosion, the calculated root cohesion for the four grasses in this investigation could be helpful for controlling bank erosion in the riparian zone of TGR.

\section{Conclusions}

The RAR and root tensile strength of four grass species growing on the riparian zone of TGR were measured to estimate soil reinforcement by the roots using the model by Wu et al. (1979) and to rank the potential of species in preventing bank erosion. The present results develop the understanding on root reinforcement of several grass species in the riparian zone of the TGR. The root tension tests revealed a power relationship between root diameter and tensile strength. Moreover, the higher root cohesion associated with $H$. altissima and $H$. compressa implies that they are better selections for revegetation purposes to reinforce the topsoil area through the additional root cohesion. C. dactylon presented the least efficiency for soil reinforcement with the lowest root cohesion values. $P$. paspaloides showed an intermediate effect. Although the relative efficiency of grass roots for soil reinforcement is only assessed from indirect indicators, the experiments performed in the present investigate together with the understanding of species tolerance to flooding, and their resistance to concentrated flow erosion could be helpful for plant selection in the project of 
implementing and future revegetation actions in the riparian zone of TGR and similar riparian zones in the Yangtze River Basin.

\section{Acknowledgements}

Financial support for this study was jointly provided by the National Natural Science Foundation of China (Grant No. 41201272), the Chinese Academy of Sciences Action-plan for West Development (Grant No. KZCX2-XB3-09) and the

\section{References}

Abernethy B, Rutherfurd ID (2001) The distribution and strength of riparian tree roots in relation to riverbank reinforcement. Hydrological Processes 15: 63-79. DOI: 10.1002/hyp. 152

Adhikari AR, Gautam MR, Yu, ZB, et al. (2013) Estimation of root cohesion for desert shrub species in the Lower Colorado riparian ecosystem and its potential for streambank stabilization. Ecological Engineering 51: 33-44. DOI: 10.1016/ j.ecoleng.2012.12.005

Bao YH, Tang Q, He XB, et al. (2013) Soil erosion in the riparian zone of the Three Gorges Reservoir, China. Hydrology Research. DOI:10.2166/nh.2013.291

Bischetti GB, Chiaradia EA, Simonato T, et al. (2005) Root strength and root area ratio of forest species in Lombardy (Northern Italy). Plant and soil, 278: 11-22. DOI: 10.1007/ 978-1-4020-5593-5_4

Burylo M, Hudek C, Rey F (2011) Soil reinforcement by the roots of six dominant species on eroded mountainous manly slopes (Southern Alps, France). Catena 84: 70-78. DOI: 10.1016/j.catena.2010.09.007

Sun BX, Sylvia MP (2006) Poaceae. In: Wu ZY, Raven PH, Hong DY (eds) Flora of China. Vol. 22. Science Press, Beijing and Missouri Botanical Garden Press, St Louis. pp 482-493 + 640-642.

Chen SL, Sylvia MP (2006) Poaceae. In: Wu ZY, Raven PH, Hong DY (eds.) Flora of China. Vol. 22. Science Press, Beijing and Missouri Botanical Garden Press, St Louis. pp 526-530.

Comino E, Marengo P (2010) Root tensile strength of three shrub species: Rosa canina, cotoneaster dammeri and juniperus horizontalis soil reinforcement estimation by laboratory tests. Catena 82: 227-235. DOI: 10.1016/j.catena. 2010.06.010

Comino E, Marengo P, Rolli V (2010) Root reinforcement effect of different grass species: A comparison between experimental and models results. Soil and Tillage research 110: 60-68. DOI:10.1016/j.still.2010.06.006

Coutts MP, Nielsen CCN, Nicoll BC (1999) The development of symmetry, rigidity and anchorage in the structural root system of conifers. Plant and soil 217: 1-15. DOI: 10.1023/ A:1004578032481

Craine JM (2006) Competition for nutrients and optimal root allocation. Plant and soil 285: 171-185. DOI: 10.1007/s11104006-9002-x

Day SD, Wiseman PE, Dickinson SB, et al. (2010) Tree root ecology in the urban environment and implications for a sustainable rhizosphere. Arboriculture and Urban Forestry 36 : 193-205.

De Baets S, Poesen J, Knapen A, Galindo P (2007) Impact of root architecture on the erosion-reducing potential of roots
Chinese Academy of Science (Light of West China Program). The authors are thankful to all persons involved in the field investigation and data preparation of this project. We also thank the editors and the two anonymous reviewers for constructive comments and valuable recommendations regarding this manuscript.

\section{Electronic Supplementary Material:} Supplementary specification for formulas is available in the online version of this article at http://dx.doi.org/10.1007/s11629-014-3397-2 during concentrated flow. Earth Surface Processes and Landforms 32: 1323-1345. DOI: 10.1002/esp.1470

De Baets S, Poesen J, Reubens B, et al. (2008) Root tensile strength and root distribution of typical Mediterranean plant species and their contribution to soil shear strength. Plant and soil 305: 207-226. DOI: 10.1007/s11104-008-9553-0

Dupuy L, Fourcaud T, Stokes A (2005) A numerical investigation into the influence of soil type and root architecture on tree anchorage. Plant and soil 278: 119-134. DOI: $10.1007 / 978-1-4020-5593-5 \_17$

Ennos AR (1990) The Anchorage of Leek Seedlings - the Effect of Root Length and Soil Strength. Annals of Botany 65: 409-416. FAO (2015) Grassland Index. A searchable catalogue of grass and forage legumes. FAO, Rome, Italy. Available online at: http://www.fao.org/ag/AGP/AGPC/doc/GBASE/commonna mes/commonsearch.htm (Accessed on 15 January 2015)

Fan CC, Su CF (2008) Role of roots in the shear strength of root-reinforced soils with high moisture content. Ecological Engineering 33: 157-166. DOI:10.1016/j.ecoleng.2008.02.013

Fu BJ, Wu BF, Lü YH, et al. (2010) Three Gorges Project: Efforts and challenges for the environment. Progress in Physical Geography 34: 741-754. DOI: 10.1177/03091 33310370286

Genet M, Stokes A, Salin F, et al. (2005) The influence of cellulose content on tensile strength in tree roots. Plant and soil 278: 1-9. DOI: 10.1007/s11104-005-8768-6

Giadrossich F, Schwarz M, Cohen D, et al (2013) Mechanical interactions between neighbouring roots during pullout tests. Plant and Soil 367: 391-406. DOI: 10.1007/s11104-012-1475-1

Glinski J, Lipiec J (1990) Soil physical conditions and plant roots. Boca Raton, FL: CRC Press.

Goodman AM, Ennos AR (1999) The effects of soil bulk density on the morphology and anchorage mechanics of the root systems of sunflower and maize. Annals of Botany 83: 293302. DOI: 10.1006/anbo.1998.0822

Gray DH (1974) Reinforcement and Stabilization of Soil by Vegetation. Journal of the Geotechnical Engineering Division 100: 695-699.

Gray DH, Barker D (2004) Root-soil mechanics and interaction. In: Bennett SJ, Simon A. (eds.), Riparian Vegetation and Fluvial Geomorphology., American Geophysical Union., New York, NY, USA. pp. 113-123.

Gray DH, Leiser AT (1982) Biotechnical Slope Protection and Erosion Control, Van Nostrand-Reinhold, New York.

Gray DH, Sotir RB (1996) Biotechnical and Soil Bioengineering Slope Stabilization: A Practical Guide for Erosion Control, John Wiley and Sons, New York, USA.

Greenwood J R (2007) SLIP4EX - A program for routine slope stability analysis to include the effects of vegetation, 
reinforcement and hydrological changes. Eco- and Ground Bio-Engineering: The Use of Vegetation to Improve Slope Stability 103: 193-202. DOI: $10.1007 / 978-1-4020-5593-5 \_18$

Gyssels G, Poesen J (2003) The importance of plant root characteristics in controlling concentrated flow erosion rates. Earth Surface Processes and Landforms 28: 371-384. DOI: 10.1002/esp.447

Gyssels G, Poesen J, Bochet E, et al. (2005) Impact of plant roots on the resistance of soils to erosion by water: a review. Progress in Physical Geography 29: 189-217. DOI: 10.1191/ 0309133305pp443ra

Hathaway RL, Penny D (1975) Root strength in some Populus and Salix clones. New Zealand Journal of Botany 13: 333-344. DOI: 10.1080/0028825X.1975.10430330

He XB, Bao YH, Nan HW, et al. (2009) Tillage pedogenesis of purple soils in southwestern China. Journal of Mountain Science 6: 205-210. DOI: 10.1007/s11629-009-1038-y

He YR (2003) Purple soil in china (2). Science Press, Beijing, China. pp 59-90. (In Chinese)

Hefting MM, Clement JC, Bienkowski P, et al. (2005) The role of vegetation and litter in the nitrogen dynamics of riparian buffer zones in Europe. Ecological Engineering 24: 465-482. DOI: 10.1016/j.ecoleng.2005.01.003

Hodge A (2004) The plastic plant: root responses to heterogeneous supplies of nutrients. New Phytologist 162: 924. DOI: 10.1111/j.1469-8137.2004.01015.x

Hubble TC, Docker BB, Rutherfurd ID (2010) The role of riparian trees in maintaining riverbank stability: A review of Australian experience and practice. Ecological Engineering 36: 292-304. DOI:10.1016/j.ecoleng.2009.04.006

Li Y, Zhu XM, Tian JY, et al. (1990) A preliminary-study on mechanism of soil anti-scourability on the loess plateau. Chinese Science Bulletin 35: 1565-1569.

Li Y, Zhu XM, Tian JY, et al. (1991) Effectiveness of plant-roots to increase the anti-scourability of soil on the loess plateau. Chinese Science Bulletin 36: 2071-2082.

Li Y, Xu XQ, Zhu XM (1993) Effective model on the roots of chinese pine plantation to improve the physical properties of soil in the loess plateau. Scientia Silvae Sinicae 29: 193-198. (In Chinese)

Liu YF (2010) Bank Collapse Erosion in Water Level Fluctuating Zone of the Three Gorges Reservoir via BSTEM. Master thesis, the Graduate School of Chinese Academy of Sciences, Beijing., China. pp 71-73. (in Chinese)

Lu ZJ, Li LF, Jiang MX, et al. (2010) Can the soil seed bank contribute to revegetation of the drawdown zone in the Three Gorges Reservoir Region? Plant Ecology 209: 153-165. DOI: 10.1007/s11258-010-9732-y

Mao Z, Yang M, Bourrier F, et al. (2014) Evaluation of root reinforcement models using numerical modelling approaches. Plant and soil 381: 249-270. DOI: 10.1007/s11104-014-2116-7

Mattia C, Bischetti GB, Gentile F (2005) Biotechnical characteristics of root systems of typical Mediterranean species. Plant and soil 278: 23-32. DOI: 10.1007/s11104-0057930-5

Mickovski SB, Hallett PD, Bransby MF, et al. (2009) Mechanical Reinforcement of Soil by Willow Roots: Impacts of Root Properties and Root Failure Mechanism. Soil Science Society of America Journal 73: 1276-1285. DOI: 10.2136/sssaj2008.0172

Mickovski SB, Van Beek LPH (2009) Root morphology and effects on soil reinforcement and slope stability of young vetiver (Vetiveria zizanioides) plants grown in semi-arid climate. Plant and Soil 324: 43-56. DOI: 10.1007/s11104-0090130-y

New T, Xie ZQ (2008) Impacts of large dams on riparian vegetation: applying global experience to the case of China's Three Gorges Dam. Biodiversity and Conservation 17: 31493163. DOI: $10.1007 /$ s10531-008-9416-2

Nilaweera, NS, Nutalaya P (1999) Role of tree roots in slope stabilization. Bulletin of Engineering Geology and the Environment 57: 337-342.
Norris JE (2005) Root reinforcement by hawthorn and oak roots on a highway cut-slope in Southern England. Plant and Soil 278: 43-53. DOI: 10.1007/s11104-005-1301-0

Operstein V, Frydman S (2000) The influence of vegetation on soil strength. Proceedings of the ICE - Ground Improvement 4: 81-89. DOI: $10.1680 /$ grim.2000.4.2.81

Pollen-Bankhead N, Simon A (2010) Hydrologic and hydraulic effects of riparian root networks on streambank stability: is mechanical root-reinforcement the whole story? Geomorphology 116: 353-362. DOI: 10.1016/j.geomorph. 2009.11.013

Pollen N, Simon A (2005) Estimating the mechanical effects of riparian vegetation on stream bank stability using a fiber bundle model. Water Resources Research 41: 1-11. DOI: 10.1029/2004WRo03801

Polvi LE, Wohl E, Merritt DM (2014) Modeling the functional influence of vegetation type on streambank cohesion. Earth Surface Processes and Landforms 39: 1245-1258. DOI: 10.1002/esp.3577

Quine CP, Burnand AC, Coutts MP, et al. (1991) Effects of Mounds and Stumps on the Root Architecture of Sitka Spruce on a Peaty Gley Restocking Site. Forestry 64: 385-401. DOI: 10.1093/forestry/64.4.385

Reubens B, Poesen J, Danjon F, et al. (2007) The role of fine and coarse roots in shallow slope stability and soil erosion control with a focus on root system architecture: a review. Trees-Structure and Function 21: 385-402. DOI: 10.1007/ s00468-007-0132-4

Sarkar AN, Jenkins DA, Wyn Jones, RG (1979) Modifications to mechanical and mineralogical composition of soil within the rhizosphere. In Harley, JL and Russell RS, editors,. The soilplant interface. London: Academic Press.

Schwarz M, Lehmann P, Or D (2010) Quantifying lateral root reinforcement in steep slopes - from a bundle of roots to tree stands. Earth Surface Processes and Landforms 35: 354-367. DOI: 10.1002/esp.1927

Shi ZL,Wen AB, Zhang XB, et al. (2011) Comparison of the soil losses from $7 \mathrm{Be}$ measurements and the monitoring data by erosion pins and runoff plots in the three gorges reservoir region, China. Applied Radiation and Isotopes 69: 1343-1348. DOI: 10.1016/j.apradiso.2011.05.031

Simon A, Collison AJC (2002) Quantifying the mechanical and hydrologic effects of riparian vegetation on streambank stability. Earth Surface Processes and Landforms 27: 527-546. DOI: $10.1002 /$ esp. 325

Simon A, Pollen N, Langendoen E (2006) Influence of two woody riparian species on critical conditions for streambank stability: Upper Truckee River, California. Journal of the American Water Resources Association 42: 99-113. DOI: 10.1111/j.1752-1688.2006.tbo3826.x

Smit AL, Bengough AG, Engels C, et al. (Eds.) (2000) Root methods: a handbook, Springer-Verlag, Berlin.

Stokes A, Atger C, Bengough AG, et al. (2009) Desirable plant root traits for protecting natural and engineered slopes against landslides. Plant and Soil 324: 1-30. DOI: 10.1007/ s11104-009-0159-y

Tang Q, Bao YH, He XB, et al. (2014) Sedimentation and associated trace metal enrichment in the riparian zone of the Three Gorges Reservoir, China. Science of the Total Environment 479: 258-266. DOI: 10.1016/j.scitotenv.2014. 01.122

Tenten N, Zeng B, Kazda M (2010) Soil stabilizing capability of three plant species growing on the Three Gorges Reservoir riverside. Journal of Earth Science 21: 888-896. DOI: 10.1007/s12583-010-0142-9

Thomas RE, Pollen-Bankhead N (2010) Modeling root-

reinforcement with a fiber-bundle model and Monte Carlo simulation. Ecological Engineering 36: 47-61. DOI: 10.1016/j. ecoleng.2009.09.008

Tosi M (2007) Root tensile strength relationships and their slope stability implications of three shrub species in the 
Northern Apennines (Italy). Geomorphology 87: 268-283. DOI: 10.1016/j.geomorph.2006.09.019

Waldron L, Dakessian S (1981) Soil reinforcement by roots: calculation of increased soil shear resistance from root properties. Soil science 132: 427-435. DOI: 10.1097/ 00010694-198112000-00007

$\mathrm{Wu}$ TH (2013) Root reinforcement of soil: review of analytical models, test results, and applications to design. Canadian Geotechnical Journal 50: 259-274. DOI: 10.1139/cgj-20120160

Wu TH, McKinnell III PM, Swanston DN (1979) Strength of tree roots and landslides on Prince of Wales Island, Alaska. Canadian Geotechnical Journal 16: 19-33. DOI: 10.1139/t79-003

$\mathrm{Xu} \mathrm{XB}$, Tan Y, Yang GS (2013) Environmental impact assessments of the Three Gorges Project in China: Issues and interventions. Earth-Science Reviews 124: 115-125. DOI: 10.1016/j.earscirev.2013.05.007

Ye C, Cheng XL, Zhang QF (2014) Recovery approach affects soil quality in the water level fluctuation zone of the Three Gorges Reservoir, China: implications for revegetation. Environmental Science and Pollution Research 21(3): 20182031. DOI: 10.1007/s11356-013-2128-5

Ye C, Cheng XL, Zhang YL, et al. (2012) Soil nitrogen dynamics following short-term revegetation in the water level fluctuation zone of the Three Gorges Reservoir, China.
Ecological Engineering 38: 37-44. DOI: 10.1016/j.ecoleng. 2011.10.005

Ye C, Li SY, Zhang YL, et al. (2011) Assessing soil heavy metal pollution in the water-level-fluctuation zone of the Three Gorges Reservoir, China. Journal of Hazardous Materials 191: 366-372. DOI: 10.1007/s10661-012-2547-7

Ye C, Zhang KR, Deng Q, et al. (2013) Plant communities in relation to flooding and soil characteristics in the water level fluctuation zone of the Three Gorges Reservoir, China. Environmental Science and Pollution Research 20: 1794-1802. DOI: 10.1007/s10661-012-2547-7

Zhang CB, Chen LH, Jiang J (2014) Why fine tree roots are stronger than thicker roots: The role of cellulose and lignin in relation to slope stability. Geomorphology 206: 196-202. DOI: 10.1016/j.geomorph.2013.09.024

Zhang ZY, Wan CY, Zheng ZW, et al. (2013) Plant community characteristics and their responses to environmental factors in the water level fluctuation zone of the three gorges reservoir in China. Environmental Science and Pollution Research 20: 7080-7091. DOI: 10.1007/s11356-013-1702-1

Zhao CM, Chen WL, Huang HD, et al. (2007) Spatial pattern of plant species diversity in the inundation and resettlement region of the Three Gorges Reservoir. Biodiversity Science 15: 510-522. DOI: 10.1360/biodiv.070084 (In Chinese) 